\title{
ERRATUM
}

\section{THE PUBLIC-PRIVATE DIVIDE IN ENGLISH AND DUTCH LAW: A MULTIFUNCTIONAL AND CONTEXT-DEPENDANT DIVIDE}

\author{
G. JURGENS AND F. VAN OMMEREN
}

doi:10.1017/S0008197312000244. First published by Cambridge University Press March 2012.

During the correction process errors were introduced regarding the email address of author G. Jurgens and the omission of the address for correspondence for F. van Ommeren, for which the publisher and editor apologises.

The correct details are given below.

The email address for G. Jurgens should read:

g.jurgens@uu.nl

The address for correspondence for F. van Ommeren is:

Professor Dr Frank van Ommeren, Centre of Law and Governance, VU University of Amsterdam, De Boelelaan 1105, 1081 HV Amsterdam, The Netherlands. Email: f.j.van.ommeren@vu.nl

\section{REFERENCE}

G. Jurgens and F. van Ommeren (2012). The Public-Private Divide in English and Dutch Law: A Multifunctional and Context-Dependant Divide. CLJ, Volume 71, Part I. doi:10.1017/S0008197312000244. 